\title{
Implementation of Green Campus-Based Curriculum Model at Islamic Universities in Indonesia
}

\author{
Indra Jaya \\ State Islamic University of North Sumatera, Indonesia \\ e-mail:indrajaya@uinsu.ac.id
}

\begin{abstract}
This study is aimed to investigate the implementation of green campus-based curriculum model at Islamic universities in Indonesia. In depth interview was conducted to the top leader of universities in order to confirm the application of green campus-based curriculum especially on vision and mission. A set of interviews was also questioned to lecturers to obtain important information regarding with the employment of the model of curriculum related to environmental health they used in classrooms. In addition, supporting data about students from lecturers' information was also occupied to enrich the data. As a result, the researcher found that all Islamic universities observed in this study imply green campus or environmental aspect points in university's vision and mission. Less than $100 \%$ of lecturers are able to design learning materials related to environmental health as well as implementing it in classrooms. Less than $60 \%$ of students can produce environmental work arts as well as having problem solving skills toward surrounding environment. Above all, hose Islamic universities determine similar goals on green campus-based curriculum model i.e. to preserve the environment and aware of surrounding natural issues. At the end, a few suggestions were suggested to the top manager of the Islamic universities concerning with vital element regarding with lecturers' competencies in developing environmental health learning design that should be noticed and increased.
\end{abstract}

Keywords: green campus-based curriculum, higher education curriculum, environmental health

\section{A. Introduction}

Higher education in addition to having the capacity to develop science, technology and art, sustainable higher education also requires support from an environmentally friendly university in carrying out the implementation of tree pillars of higher education or what so 
called by "Tridarma Perguruan Tinggi". Particularly, green campus is a manifestation of a comfortable, safe, beautiful and energy-efficient university environment; in order to support university dynamic development in a conducive academic climate. This condition will indirectly form a new behavior pattern for university communities which is dynamic, global, and sustainable (Peraturan Rektor Universitas Sebelas Maret, 2015).

Environmental health education is important because its existence is potential to increase human resources as well as improving students' ability toward environmental knowledge (Marliana \& Hikmah, 2013). In 1970s and 1980s, awareness toward environmental health education has raised starting from low and middle levels of education up to higher level i.e. university level. In a research conducted by Hus (2010), environmental studies appeared in primary level of education, and as social condition changed, subjects of environmental studies also changed by following the newest regulation by the education affair of primary school system. Therefore, Hus (2010) described the characteristics of new curriculum design regarding with environmental studies subjects.

New ideas and various activities have provided for students such as conducting a preservation movement (Bolstad, 2005). At the present time, a number of public Islamic universities continue to improve quality education as well as comfortable environment for students. These Islamic universities are competing in implementing green universities policy in every syllabus that refers to curriculum in order to bring fresh atmosphere to academic situation for students to learn. In world growing development with the decrease of health environmental quality, Islamic universities should become a pioneer toward the implementation of environmental management as well as becoming a leading university to actualize green campus program.

The problem encountered was how to understand and apply well management, especially in the field of environmental health education at Islamic Universities in Indonesia. In addition, there are different perceptions in describing as well as implementing environmental-based curriculum into each course exist in every department at a university. Specifically, academic components in a university who are not well-understood about the concept of environmental health education in curriculum will result policies which are not in line with it. Therefore, leadership in the case of environmental health in higher education is needed. An effort such as conducting Asian Program for Incubation of Environmental Leaders (AIPEL) which has been studied by An et al. (2011) is very interesting to highlight since its existence provides such environmental issues as well as giving better understanding on how to solve various environmental problems. In accordance with An et al. (2011), Karem et al. (2010) also pointed that curriculum nowadays miscarried on bringing students to understand how to solve environmental problems. Other than that, Karem et al. (2010) add that today's curriculum unsuccessful on carrying out the relationship between human and environment. This problem can be seen from both at public and private Islamic universities which do not reflect clean and healthy Islamic universities. This research is significantly important because Islamic universities should implement the management of healthy environment education which rely on Islamic concept which are existed in curriculum. Unfortunately, in fact, there are a number of nonIslamic universities implement the concept of green campus. In this case, Islamic universities should have become an agent of implementing healthy environment because Islam has taught us to love cleanliness and preserve surround environment. 
Other than above problems, Karimzadegan \& Meiboudi (2012) argued that in lower level of education, textbook for students as one of important sources for learning environmental health education should be reflected well such as on science book so that it becomes one of factors that drive lack of students' attention toward their environment. Almost the same with Karimzadegan \& Meiboudi (2012), HUS (2013) also investigated environmental studies textbook used by teachers as well as how teachers implement the environmental studies subject when teaching students as it is not easy to transfer theoretical knowledge to practice.

Knowing that there are various environment problems exist, several researchers have conducted studies toward environmental issues. It is Bakhtiar (2016) who conducted a research about environmental health curriculum by developing it through five points of local wisdom characteristics i.e. local farming, green open land, water treatment, food product processes, and pattern on local community. Surprisingly that the research of Bakhtiar (2016) gained significant result by implementing three steps in managing the data i.e. preliminary study, planning design development, and try out and revision. Kind of similar with Bakhtiar (2016), Hariyati \& Namat (2017) also investigated about the implementation of environmental-based curriculum through three steps i.e. planning, implementation, and evaluation.

Meanwhile, another researcher, Lateh \& Muniandy (2010) tried to offer a solution of introducing Environmental Education (EE) to lecturers as well as digging their comprehending toward this environmental management tool. It is intended to build a strategy to increase awareness of environmental health by introducing it at formal and non-formal education. Lecturers or teachers as one of components at educational institution takes a vital role to determine school success. Therefore, they deserve to have proper training as a provision in teaching the students how to implement environmental health preservation and management from small to bigger boarders (Pe'er, Goldman, \& Yavetz, 2007).

In this case, all of previous studies pointed out above were conducted at lower level education i.e. primary graders. It is plausible that environmental health education should be started at early age, but the researcher believed that this world future needs sustainable educational system which contained environmental health education courses to be learned by students of university. Therefore, the existence of green campus concept is very interesting to be raised nowadays especially when seeing the fact happened at our natural environmental phenomenon, this research intends to investigate green campus curriculum model at a number of Islamic universities in Indonesia, based on an assumption that healthy environment is a must and becomes a prior need for human in general. To actualize this point, knowledge transformation is needed regarding with sustainable living environment through the integration of healthy environment point of education in learning curriculum in Islamic universities.

\section{B. Literature Review}

\section{Environmental-Based Education Curriculum}

Curriculum is an important aspect in an education process. Its existence is a well-planned and organized efforts on creating students' learning experience under school accountability. Specifically, the concept of curriculum in general is not merely in the form of courses or learning activities of students, but it refers to every element affected students' character building in accordance to intended education goals (Alberty \& Alberty, 1965). Environmental literacy and education goals tend to produce practical outcomes by preserving an appropriate environmental system and following by the action to maintain and increase environmental 
health quality (Karimzadegan \& Meiboudi, 2012). Basically, Hamalik (2008) pointed out that there are eight principles of curriculum including goal-oriented, conformity, efficiency and affectivity, flexibility, continuity, stability, integrity, and quality. In this case, environmentalbased curriculum is important because it is considered as one of parts in integrity where educational institution is possible to assimilate learning process with environmental education. In addition, UNESCO (1991) explained that environmental-based curriculum is also related to the principle of continuity because sustainable development is the ultimate goal of the relationship between humans and environment. Therefore, the whole education must be reformed for continuous development by optimizing environment as the basic resource (World Commission on Environment and Development, 1987).

Generally, the aim of environmental health education is changing the attitude of individual and society toward the actualization of optimal health (Notoatmodjo, 1997; Effendi, 1995). In addition, Notoatmodjo (1997) explained that the goal of environmental health education is to build awareness and increase public knowledge related to health care for community. Strategies for implementing environmental education were developed from personal development to be more environment oriented (Gagne, 1977). Moreover, curriculum with environmental-based is focal because naturally, humans are connected to environment including human and natural resources, technology, and so forth (Singh \& Dogra, 2014). The effort that is possible to apply is integrating social reconstruction curriculum, curriculum of academic subjects, as well as technology so that it can be used in the middle and at the end of learning process. School management can emphasize students' activities to seek how to understand certain object, learn to analyze and reconstruct, so that new knowledge is formed within the students. This sort of activities will drive students to not only learn theoretical knowledge but also more applied aspect to make students mature personally because they are trained at school to have empathy toward everything around them (Gagne, 1977).

Related to possible students' activities in learning which has been pointed out by Gagne (1977), we also should notice that it is an urgent matter to develop the typology paradigm of environmental education which include rational education paradigm, humanistic education paradigm, and inventive education paradigm (Bertrand \& Valois, 1992). Specifically, rational education paradigm is related to industrial social culture which is indicated by the importance of relationship among production, productivity, social growth and competition. This type of paradigm is connected to scientific and technical knowledge transmission by providing certain teaching strategies e.g. formal presentation, demonstration, and assignment. The second paradigm in environmental education i.e. humanistic paradigm which is concerning with extential socio-cultural paradigm which emphasizes optimal personal achievement in accordance with potential and desires of each individual of students. This paradigm highlights more on subjectivity and the process of students' learning. The paradigm of environmental education which is inventive paradigm is associated with symbiosynergic socio-culture paradigm. It focuses on symbiosis relationship among humans and nature which aimed at creating open-minded educational institution toward real world by providing students tasks such as problem solving.

Furthermore, Sauvé $(1992 ; 1994)$ pointed out the concept of learning paradigm as well as possible learning strategies which consist of relationship between human and nature on below table: 
Table 2.1 Typology of Environmental education based on Sauvé (1992; 1994)

\begin{tabular}{|l|l|l|l|}
\hline \multicolumn{1}{|c|}{ Environment } & \multicolumn{1}{|c|}{ Type of relationship } & \multicolumn{1}{|c|}{ Characteristic } & Example of learning strategies \\
\hline as nature & $\begin{array}{l}\text { to be respected, } \\
\text { appreciated, defended }\end{array}$ & original and pure environment & $\begin{array}{l}\text { a. nature display } \\
\text { b. involvement in nature }\end{array}$ \\
\hline as a resource & to be managed & $\begin{array}{l}\text { including all biophysical } \\
\text { elements, maintaining life } \\
\text { quality }\end{array}$ & $\begin{array}{l}\text { a. 3R campaigns } \\
\text { b. examine energy } \\
\text { consumption }\end{array}$ \\
\hline as a problem & to be solved & $\begin{array}{l}\text { biophysical environment, life } \\
\text { supporting, threatened by } \\
\text { pollution, decadency }\end{array}$ & $\begin{array}{l}\text { a. problem solving } \\
\text { b. case study strategy }\end{array}$ \\
\hline $\begin{array}{l}\text { as a place of } \\
\text { living }\end{array}$ & $\begin{array}{l}\text { to know, learn, plan, } \\
\text { assure }\end{array}$ & $\begin{array}{l}\text { everyday socio-cultural } \\
\text { environment, technology, } \\
\text { hystorical component }\end{array}$ & $\begin{array}{l}\text { a. story of surrounding } \\
\text { environment } \\
\text { gardening project }\end{array}$ \\
\hline as biosphere & where we live, for future & $\begin{array}{l}\text { Spacecraft, planetary objects, } \\
\text { reliance between human beings } \\
\text { and things }\end{array}$ & $\begin{array}{l}\text { a. case study on global issues } \\
\text { b. story telling about } \\
\text { cosmology }\end{array}$ \\
\hline $\begin{array}{l}\text { as a project } \\
\text { community }\end{array}$ & to get involved & $\begin{array}{l}\text { Share environmental living, } \\
\text { focus on socially critical } \\
\text { analysis, political attention for } \\
\text { society }\end{array}$ & $\begin{array}{l}\text { a. central action research } \\
\text { borum of environmental } \\
\text { issues }\end{array}$ \\
\hline
\end{tabular}

\section{Research Methodology}

This research was done at four Islamic Universities in Indonesia i.e. UIN Ar-Raniry, Aceh, UIN Maulana Malik Ibrahim, Malang, UIN Sunan Kalijaga Yogyakarta, and UIN Syarif Hidayatullah, South Tanggerang. Qualitative approach with Weberian perspective or sociocultural perspective, which is proposed by Weber, is applied in this research in order to understand through empathy (Taylor \& Bogdan, 1998; Taylor, Bogdan, \& DeVault, 2016). In addition, perspective emphasizes efforts on interpreting an individual person, institutions as individuals, individual actions, and style of work (Taylor \& Bogdan, 1998; Taylor et al., 2016).

Moreover, a set of in depth interview were asked to top leader of above four Islamic universities to investigate the vision and mission existed. In this case, vision and mission were analyzed because every aspect in a university should reflect the education goal that a university would like to achieve stated on vision and mission. In addition, interview was also prepared and conducted for lecturers to ensure the implementation of green campus curriculum model reflected in courses being taught in classrooms. As a supporting data in this research, the researcher also inquired for lecturers' information regarding with several aspects of environmental health related to students. Curriculum document analysis was also analyzed to point out what sort of green campus curriculum model those Islamic universities set and apply.

\section{Findings}

In order to actualize health-based education in university level, it is found that there is similarity in terms of strengthening vision and mission designed by university related to environmental health. Only two out of four universities include more than two points of environmental health management and protection. It is said that those universities vision and mission come from knowledge and understanding toward surah Luqman verse 20 and surah Ar- 
Rum verse 41. Additionally, elements of those universities i.e. students, lecturers, and university's manager also have enough understanding toward vision and mission of their universities in actualizing environmental health management. It is indicated by two types of sources i.e. university's vision and mission documents as well as interview conducted to students, lecturers, and top management of the universities.

Other than environmental health management reflected in vision and mission, policy in curriculum structure is also observed in this research. From the result, it is showed that three of four universities have accommodated preservation of environmental function, prevention environment from pollution and damage, as well as management of liquid and solid waste disposal. In addition, those universities also have integrated air quality management, quality of residential environment, and how to manage dangerous goods around universities.

Furthermore, as Islamic university, it is very important to have knowledge about two vital sources in Islam i.e. Al-Qur'an and Hadith especially regarding with environmental health. In this case, UIN Ar-Raniry, Aceh and UIN Sunan Kalijaga Yogyakarta mentioned that lecturers are able to comprehend surah in Al-Qur'an as well as Hadith regarding with environment as nature, natural resources, problems, place of living, and biosphere. In addition, the lecturers also can integrate it toward classroom teaching and learning. Not only from the lecturers' side, at UIN Ar-Raniry, Aceh and UIN Sunan Kalijaga Yogyakarta, the students are able to understand that Islam is a solution of all environmental problems. Whereas at UIN Syarif Hidayatullah, Jakarta and UIN Maulana Malik Ibrahim, Malang, they mentioned that 50-70\% of lecturers can apply problem solving of environmental cases as well as environmental story telling method which involve students directly to the process of teaching and learning related to environment.

In terms of designing learning materials, the data showed that $50-70 \%$ lecturers at UIN Syarif Hidayatullah, Jakarta and UIN Maulana Malik Ibrahim, Malang are able to design learning materials related to protection and management of environmental health. Meanwhile, more than 70\% lecturers at UIN Sunan Kalijaga, Yogyakarta and UIN Ar-Raniry, Aceh can design learning materials regarding with environmental health such as environment function as biosphere.

Not only from lecturers, students were also investigated related to the role of students in producing any environmental works and arts. In this case, at UIN Syarif Hidayatullah, Jakarta and UIN Maulana Malik Ibrahim, Malang, 30-50\% of the students can produce beneficial works concerning with drinking water supply. Meanwhile, students at UIN Sunan Kalijaga, Yogyakarta can produce real works related to how to prevent noise pollution. Different case with previously mention universities, 10-29\% students at UIN Ar-Raniry, Aceh can create a product on how to prevent infectious diseases through vectors and manage water quality in university environment.

Furthermore, it is urgent for students to have problem solving skills regarding with surrounding environment. The data found that 10-29\% students at UIN Syarif Hidayatullah, Jakarta and UIN Maulana Malik Ibrahim, Malang are able to solve problems regarding with environmental health such as gas waste, prevention from accident, congenital diseases, and infectious diseases through saliva, air, and food. In addition, the researcher also obtained additional data which is showed that more than 50\% students at UIN Kalijaga, Yogyakarta can solve environmental problem around university such as drinking water supply and liquid waste disposal.

Above all, formulation of higher education curriculum model at the level of concepts and models of environmental health education management exist in all Islamic universities observed is pointed out on below chart: 


\section{College Policy}

1. More than $50 \%$ students have capability on solving environmental health problems i.e. drinking water supply, waste disposal (liquid, solid, and gas), prevention of noise pollution, accident, congenital diseases, infectious diseases through saliva, water, food, and vector, and quality management of air, surrounding environment, housing, and dangerous goods.

2. Students comprehend the essential meaning of having Islam as a solution of environmental problems through Al-Qur'an and Hadith.



Figure: Model of policy implementation 
Indra Jaya

\section{E. Discussion}

Above findings indicate that all of Islamic universities set environmental health point on their vision and mission. It is very important since vision and mission become the first vital elements in building and developing a university until designing curriculum and learning materials. This findings confirm the result of environmental-based curriculum study done by Hariyati \& Namat (2017), where in their study, they found that the goals and content of environmental-based curriculum at the school they observed is designed by adapting institutional vision and mission.

To the more particular point about goals of environmental health education exist in curriculum, as the researcher found that at the formulation of higher educational curriculum, all Islamic universities set a similar goal i.e. to create decent management to protect environment from destruction. This finding is supported by Karimzadegan \& Meiboudi (2012), Pe'er et al. (2007), Lateh \& Muniandy (2010), Gagne (1977), Notoatmodjo (1997), and Effendi (1995) stated that preservation toward environment is an urgent matter since it is not merely a subject course teaching in a classroom, but also a matter of action as an effort to build early environmental attentiveness of students.

In fact, students are motivated and naturally interested in exploring their environmental surrounding. Hence, teachers should enrich their skills on arranging students' activities which are relevant to environmental condition around them (Archie, 2003; The National Environmental Education and Training Foundation, 2000). It is crucial since at the end of pursuing education at formal institution, students will not just need theoretical knowledge, but this world require students to have practical one in order to be successful on acquiring attitude, moral values, working competencies, and managerial competencies for future (Susilo, 2015).

Furthermore, it is obvious that it is a significant matter when students can do valuable actions on surrounding environmental issues and problems as mentioned on findings above. It is imperative because lecturers need to build and teach the students on how to have empathy to what happened toward environment around their living place (Karimzadegan \& Meiboudi, 2012). It is also confirmed by the theory of typology of environmental education proposed by Sauvé $(1992,1994)$ stated that one of environmental functions is as a place of living as well as a problem. It is obviously make sense that Sauvé $(1992,1994)$ pointed that environment as a problem because it is true that various problems exist around our environment. Therefore, lecturers need to educate students on how to have problem solving skills, especially to manage environmental issues happened around them. Related to this matter, Lateh \& Muniandy (2010) explained that environmental problems become vital issues in this global modernization era. They also added that one possible factor that contributes to the neglect of environmental consciousness of students is the raising of technology. It decreases the awareness of students to manage and preserve their surrounding environment. Finally, it is suggested that typology of environmental education based on Sauvé (1992, 1994) adapted by lecturers in applying environmental health or green campus-based curriculum model since it provides not only characteristics of environment but also references related to what sort of learning strategies lecturers use in teaching especially about environmental health.

\section{F. Conclusion}

From the findings and discussion above, it can be concluded that all Islamic universities observed in this research have already applied environmental health education on their 
curriculum by including aspect of environmental health education on vision and mission as well as reflecting it on the curriculum design and implementation. In addition, all Islamic universities have similar goals stated on their environmental health curriculum i.e. building virtuous management to keep environmental health through real action of students. This goal can be achieved through upright learning sources as well as qualified lecturers. Hence, institutional managers or top leaders should consider this point by providing well training for lecturers since they play an important role in transferring knowledge to students. After all, it should be realized that building students' awareness of surrounding environmental health is not easy and need a long term to shape reinforcement. Therefore, lecturers are the one who can lead students to have environmental health awareness by providing them not only courses in classrooms but also field activities to touch practical elements of surrounding environment as well as solving environmental problems happened around them locally or globally.

\section{BIBLIOGRAPHY}

Alberty, H. B., \& Alberty, E. J. (1965). Recognizing the highschool Curriculum. New York: The Macmillan Company.

An, K., Akiyama, T., Kim, J., Hoshiko, T., \& Furumai, H. (2011). The Influence of FieldOriented Environmental Education on Leadership Development. Procedia - Social and Behavioral Sciences, 15, 1271-1275.

Archie, M. (2003). Advancing Education through Environmental Literacy. Alexandria, VA: Association for Supervision and Curriculum Development.

Bakhtiar, A. M. (2016). Curriculum Development of Environmental Education Based on Local Wisdom at Elementary School. International Journal of Learning, Teaching and Educational Research, 15(3), 20-28.

Bertrand, Y., \& Valois, P. (1992). École et Sociétés. Revue Française de Pédagogie, 101(1).

Bolstad, R. (2005). Environmental Education: A Place in the Curriculum. New Zealand Annual Review of Education, 14, 215-235.

Effendi, N. (1995). Sumber Daya Manusia Peluang Kerja dan Kemiskinan. Yogyakarta: Tiara Wacana. Gagne, R. M. (1977). The Conditions of Learning. New York: Holt Rinehart and Winston.

Hamalik, O. (2008). Dasar-dasar Pengembangan Kurikulum (2nd editio). Bandung: emaja Rosdakarya.

Hariyati, N., \& Namat, A. H. (2017). Environment-Based Curriculum Management In Primary School. Advances in Social Science, Education and Humanities Research, 118, 661-667.

Hus, V. (2010). The Curriculum for the Subject Enviromental Studies in the Primary School in Slovenia. Procedia - Social and Behavioral Sciences, 2, 5084-5088.

HUS, V. (2013). How Teachers Evaluate the Environmental Studies Subject Textbook Sets. Education and Science, 38(167), 286-296.

Karem, A. F. H. A., Osman, K., \& Meerah, T. S. M. (2010). The Effectiveness of Classroom and Non Classroom Activities on Developing Saudi Arabian Secondary Students' Environmental Values. Procedia - Social and Behavioral Sciences, 9, 408-413.

Karimzadegan, H., \& Meiboudi, H. (2012). Exploration of Environmental Literacy in Science Education Curriculum in Primary Schools in Iran. Procedia - Social and Behavioral Sciences, 46, $404-409$.

Lateh, H., \& Muniandy, P. (2010). Environmental Education (EE): Current Situational and the 
Indra Jaya

Challenges among Trainee Teachers at Teachers Training Institute in Malaysia. Procedia Social and Behavioral Sciences, 2, 1896-1900.

Marliana, M., \& Hikmah, N. (2013). Pendidikan Berbasis Muatan Lokal Sebagai Sub Komponen Kurikulum. DINAMIKA ILMU, 13(1), 105-119.

Notoatmodjo, S. (1997). Ilmu Kesehatan Masyarakat Prinsip-Prinsip Dasar. Jakarta: Rineka Cipta.

Pe'er, S., Goldman, D., \& Yavetz, B. (2007). Environmental Literacy in Teacher Training: Atitudes, Knowledge, and Environmental Behavior of Beginning Students. The Journal of Environmental Education, 39(1).

Peraturan Rektor Universitas Sebelas Maret. Pedoman Pengelolaan Kampus Ramah Lingkungan (Green Campus) Universitas Sebelas Maret. , Pub. L. No. Nomor: 827A/UN27/KP/2013.

Sauvé, L. (1992). Éléments d'une théorie du design pédagogique en éducation relative à l'environnement. Université du Québec à Montréal.

Sauvé, L. (1994). Pour une éducation relative à l'environnement. Montréal: Guérin.

Singh, A., \& Dogra, B. (2014). A Study of Environmental Awareness among Muslim Girls Pursuing Graduation Course in Bareilly Region. Journal of Environmental Science and Technology, 1(5).

Susilo, S. (2015). Curriculum of EFL Teacher Education and Indonesian Qualification Framework: A Blip of the Future Direction. DINAMIKA ILMU, 15(1), 11-24.

Taylor, S. J., \& Bogdan, R. (1998). Introduction to Qualitative Research Methods (3rd ed.). New Jersey: Wiley.

Taylor, S. J., Bogdan, R., \& DeVault, M. L. (2016). Introduction to Qualitative Research Methods : a Guidebook and Resource (4th ed.). New Jersey: John Wiley \& Sons, Inc.

The National Environmental Education and Training Foundation. (2000). Environment-Based Education: Creating High Performance Schools and Students. Washington, DC: National Environmental Education and Training Foundation.

UNESCO. (1991). Environment and Development: A Global Commitment. Retrieved November 14, 2019, from https://unesdoc.unesco.org/ark:/48223/pf0000090256

World Commission on Environment and Development. (1987). Our Common Future. Oxford: Oxford University Press. 